\title{
KRITIK ADJIDARMA DALAM EMPAT CERPEN: TENTANG GENDER DAN KELIYANAN
}

\author{
(Adjidarma's Critics in Four Short Stories: About Gender and "Keliyanan") \\ Resti Nurfaidah \\ Balai bahasa Jawa Barat \\ Jalan Sumbawa Nomor 11, Bandung 40113, Jawa Barat, Indonesia \\ Pos-el: sineneng1973@gmail.com
}

\begin{abstract}
Abstrak: Seno Gumira Ajidarma dikenal sebagai seorang tokoh masyarakat yang multitalenta: seniman, budayawan, sastrawan, akademisi, dan lain-lain. Karya-karyanya selalu berkualitas prima dengan tingkat kedalaman aspek intrinsik yang luar biasa.Penelitian-penelitian sebelumnya menunjukkan bahwa kritik pada pemerintahan masa itu (Orde Baru) selalu muncul dalam karya Ajidarma. Namun, kritik tersebut tersembunyi di balik kepiawaiannya dalam mengolah dan merangkaikan kata menjadi cerita atau karya lain yang berkualitas prima. Penelitian ini ditujukan pada kritik sosial Ajidarma dalam empat cerpen berikut: "Pelajaran Mengarang", "Sepotong Senja untuk Pacarku", "Telinga", dan "Maria" yang difokuskan pada konsep konflik gender dan keliyanan. Berladaskan pada konsep gender Holmes dan keliyanan Callavaro, serta beberapa referensi pendukung, penelitian ini berujung pada beberapa hasil berikut: konflik gender tertuju pada inferioritas dan superioritas; ketidakberterimaan pada kriteria dan sebab tertentu menyebabkan pihak inferior menjadi korban dari kesewenang-wenangan penguasa dalam wujud: doktrinasi, pengasingan, diskriminasi, penahanan, penyiksaan, bahkan pembunuhan; inferioritas menjadi simbol atas situasi dan kondisi di negeri ini.
\end{abstract}

Kata Kunci: Seno Gumira Ajidarma, kritik sosial, Liyan, dan cerpen

\begin{abstract}
Seno Gumira Ajidarma is well-known as a multitalented popular figure in Indonesia. He is an artist, a humanist, a writer, an academician, and others. His works are always in excellent quality. They need an incredible depth level of intrinsic aspect exploration. Previous studies have shown that criticism against the government of the New Ordermassively appears on Ajidarma's writing. However, the criticism is well-hidden behind his expertise in word processing and stories composing or other excellent quality works. This research is aimed into Ajidarma's social critique in the following four short stories: "Pelajaran Mengarang", "Sepotong Senja untuk Pacarku", "Telinga", dan "Maria" which are focused on the concept of gender and Other's conflict. Based on the concepts of the Holmes gender and the Other of Callavaro, as well as several supporting references, it comes into the following outcomes: gender conflicts are connected to inferiority and superiority; the non-acceptancy of certain criteria and many causes make the inferior is victimized with the arbitrariness of the ruler in such forms: doctrine, alienation, discrimination, detention, torture, even murder; inferiority is resembling the present situation and conditions in this country.
\end{abstract}

Keywords: short stories, Seno Gumira Ajidarma, social criticism, and the Other

\section{PENDAHULUAN}

Sastra memiliki banyak fungsi, antara lain, fungsi rekreatif, fungsi moral, fungsi didaktis, fungsi reflektif, dan fungsi religius. Fungsi-fungsi tersebut sebenarnya bermuara dua fungsi utama sastra yang dikemukakan oleh Horacius, yaitu dulce et utile. Dulce bermakna kesenangan dan utile bermakna mendidik. Sastra pada masa itu ditujukan untuk menghibur sekaligus mendidik pembacanya. Sarumpaet (2010) 
menyimpukan bahwa tujuan sastra, bukan hanya pada saat itu saja, tetapi secara keseluruhan zaman adalah untuk menjadikan manusia agar mampu menjadi manusia yang sebenarnya. Sastra diperlukan untuk mengasah kepekaan mata dan hati terhadap berbagai hal yang terdapat di sekeliling manusia. Didipu (2013) lalu menguraikan kedua fungsi tersebut menjadi lima fungsi sastra berikut, yaitu fungsi estetis (sastra terbentuk dari serangkaian kata-kata yang indah), fungsi etis (penyertaan konsep moralitas dalam sebuah karya sastra), fungsi didaktis (penyertaan konsep edukatif dalam karya sastra), fungsi reflektif (cerminan kondisi sosial dalam karya sastra), serta fungsi rekreatif (adanya unsur menghibur dalam karya sastra). Artikel ini akan terkait dengan salah satu fungsi sastra tadi, yaitu fungsi reflektif, khususnya pada karya sastra berupa cerpen yang ditulis oleh Seno Gumira Ajidarma berikut: "Pelajaran Mengarang", "Sepotong Senja untuk Pacarku", "Telinga", dan "Maria".

Ajidarma (1996) merupakan sastrawan, seniman, budayawan, dan pengamat sinema yang cukup aktif. Kejelian dan kecerdasannya yang luar biasa mampu menangkap titik-titik menarik dalam kehidupan sosial-politik yang terjadi di negeri ini. Keempat cerpen tersebut ditulis pada tahun 1993 ketika rezim Orde Baru berkuasa. Pengolahan kata yang luar biasa dalam setiap karyanya seolah mampu menutup fokus-fokus sublime yang ingin disampaikan Ajidarma sebagai pengarang. Pria lulusan IKJ tahun 1977 tersebut kini memangku jabatan sebagai pucuk pimpinan di almamater tersebut, tergolong sastrawan yang aktif dalam berkarya. Beberapa karya yang dihasilkannya, antara lain: buku kumpulan puisi (Mati Mati Mati, Bayi Mati, dan Catatan-Catatan Mira Sato), buku kumpulan cerpen (Manusia Kamar, Penembak Misterius, Saksi Mata, Sebuah Pertanyaan untuk Cinta) dan novel (Negeri Senja; Jazz, Parfum, dan Insiden; Nagabumi I: Jurus Tanpa Bentuk;
Wissanggeni Sang Buronan, Biola Tak Berdawai, Kitab Omong Kosong;Kalatidha, dan Drupadi. Selain itu masih ada pula sederet karya berupa non-fiksi, drama, cerbung, dan komik. Ajidarma pernah mendapat penghargaan atas karyanya yang berjudul Saksi Mata (1995) dari Pusat Pembinaan dan Pengembangan Bahasa Depdikbud. Penghargaan lain diterima Ajidarma dari Kompas Grup pada tahun 1993 sebagai penulis cerpen terbaik dalam cerpen yang berjudul "Pelajaran Mengarang".

Fokus penelitian dalam artikel ini adalah kritik sosial dalam empat cerpen yang ditulis Ajidarma, yaitu "Pelajaran Mengarang", "Sepotong Senja untuk Pacarku", "Telinga", dan "Maria". Jika mengacu pada keempat fungsi sastra, penelitian dalam artikel ini akan menuju pada fungsi reflektif. Mengingat pada saat itu, 1993, merupakan puncak kejayaan rezim Orde Baru dengan segala pelik-pelik masalah sosialnya: pembersihan, pengangkatan kroni-kroni penguasa, dan lain-lain. Dampak ketidakadilan sosial tersebut tampak dalam keempat cerpen tersebut.

"Pelajaran Mengarang" bercerita tentang seorang anak yang mengalami kebingungan atas konsep keluarga bahagia yang dijadikan sebagai tema karangan oleh gurunya di kelas. Jika tiba pada segmen belajar mengarang, si anak selalu mengalami kesulitan. Konflik besar bergejolak di dalam hati anak itu, antara malu karena pada akhirnya ia mampu menebak profesi yang dijalani oleh ibunya sebagai seorang wanita penghibur, dan awamnya ia terhadap konsep keluarga ideal, serta kesulitan untuk memilih kata yang tepat untuk menggambarkan konflik yang dialaminya (Ajidarma, 1993b).

Cerpen "Sepotong Senja untuk Pacarku" bercerita tentang seorang laki-laki yang ingin memberi harapan kepada kekasihnya. Benda yang diinginkan kekasihnya berkaitan dengan benda milik dan diperuntukkan untuk publik. Ketika 
benda itu diambil, tentu saja lingkungan dan pemangku kekuasaan mengejar si pencuri benda itu. Laki-laki itu dituding sebagai seorang buronan. Ketika akhirnya benda itu dikembalikan, laki-laki itu tidak serta merta menjadi bebas. Cap negatif sulit diusir dari tubuhnya (Ajidarma, 1993c).

"Telinga" bercerita tentang seorang tentara yang sedang bertugas di sebuah daerah konflik. Sebagai pengobat rindu, ia gemar mengirimkan telinga para korban yang tewas dalam konflik itu kepada kekasihnya. Aneh, kekasihnya tersebut tidak merasa takut atau jijik terhadap pemberian rutin dari sang kekasih, tetapi memajang benda itu di rumah (Ajidarma, 1993d).

"Maria" bercerita tentang seorang perempuan yang menanti kehadiran anaknya di rumah. Anak lelakinya yang tampan itu diculik dan disandera. Bertahun ia menunggu kabar yang tidak pasti. Ketika si anak pulang, ia tidak mau menerimanya karena tidak mengenali lagi lelaki cacat dengan penampilan yang berantakan. Perempuan itu hanya menghendaki kepulangan anak lelakinya yang dulu, tampan dan pintar. Berbagai alasan dikemukakan, si anak tidak mendapat tanggapan. Perempuan itu akhirnya mengusir laki-laki buruk rupa itu dan mengunci pagar rumahnya rapat-rapat (Ajidarma, 1993a).

Ratna (2008) menyatakan bahwa karya seni, khususnya sastra merupakan alat atau media untuk menyatukan individu, kelompok, suku, dan bahkan antar bangsa. Melalui karya sastra, pengarang berharap dapat memiliki "pengikut" yang bersepaham dengan pola pikirnya. Untuk itu, kerapkali seorang pengarang menyelipkan pesan-pesan sosial dalam karya yang ditulisnya untuk menyampaikan kepekaan, hasil pengamatan, atau kepeduliaan sosial yang dijalaninya kepada para pembaca. Tujuannya tidak lain adalah agar pembaca mau bersepaham dengan sang pengarang. Bressler (2002) mengatakan bahwa seluruh aktivitas manusia saling mempengaruhi (interconected) secara kompleks, salah satu di antaranya, pengarang berusaha menyampaikan pengaruhnya kepada pembaca melalui karya. Meskipun demikian, adakalanya sebagian pembaca menunjukkan ketidaksepahamannya dengan sang pengarang. Dalam era digital, ketidaksepahaman dapat dilihat pada kolom komentar, atau artikel review pada beberapa laman atau media sosial. Kritik sosial pada umumnya diarahkan pada penguasa dan pernik-pernik kekuasaan, antara lain, kebijakan pemerintah dalam berbagai bidang, kekuasaan, atau hak asasi manusia. Ajidarma menunjukkan kepekaan pada lingkungan, situasi, dan kondisi di negeri ini. Pembacaan sosial Ajidarma dalam keempat cerpen tadi merujuk pada satu bahasan utama, yaitu keliyanan dalam kehidupan masyarakat. Keempat cerpen tadi akan dibahas dengan konsep representasi dan representasi keliyanan berikut.

Penelitian serupa terhadap karya Ajidarma telah dilakukan, di antaranya, (1) Indra (2015) dalam Artikel "Wacana Kekuasaan dalam Karya Seno Gumira Ajidarma, Penembak Misterius dan Saksi Mata". Indra menyimpulkan bahwa sastra dan kekuasaan memiliki hubungan yang cukup erat melalui pengungkapan praktik kekuasaan dalam karya sastra. Ajidarma melakukan hal itu dalam kedua buku kumpulan cerpen itu tentang rezim Orba. (2) Biantoro (2012) dalam skripsi yang berjudul "Kritik Sosial dalam Novel Kalatidha Karya Seno Gumira Ajidarma: Tinjauan Sosiologi Sastra" menyimpulkan bahwa dalam Kalatidha terdapat 13 kritik, antara lain, kritik terhadap pengekangan ala Orba, kritik terhadap Soeharto, stigma PKI, terhadap perbedaan status sosial antara masyarakat kota dan desa, kritik terhadap budaya materi, dan kritik terhadap pengendalian media; (3) Seputra dalam skripsi berjudul "Hubungan Intertekstual Novel Wisanggeni Sang Buronan Karya Seno Gumira Ajidarma dengan Komik 
Lahirnya Bambang Wisanggeni Karya R. Kosasih" menyatakan bahwa kedua objek penelitian memiliki relasi interteks yang kuat serta terjadinya transformasi intrinsik dari bentuk komik ke dalam novel; dan (4) Nurhadi (2004) dalam sebuah artikel berjudul "Analisis Hegemoni pada Iblis Tidak Pernah Mati Karya Seno Gumira Ajidarma" menyimpulkan bahwa dalam karya tersebut muncul konfrontasi ideologi dominan berupa kapitalisme, otoriterisme, dan militerisme terhadap ideologi marginal sosialisme, feodalisme, rasialisme, vandalisme, dan anarkisme. Namun, di antara keduanya terdapat ideologi menengah yang bertindak sebagai negosiator, yaitu demokrasi dan humanisme.

Konsep Liyan yang muncul di dalam karya Ajidarma berkaitan dengan gender. Manusia dilahirkan dengan perbedaan yang fundamental, yaitu perbedaan jenis kelamin: penis bagi laki-laki dan vagina bagi perempuan (Holmes, 2007, hlm. 21). Perjalanan hidup manusia selanjutnya merupakan sebuah rentang kehidupan panjang yang tidak dapat terhindar dari konstruksi budaya setempat. Konstruksi budaya tersebut memberikan tekanantekanan khusus terkait peranan, perilaku, hak, dan tanggung-jawab seseorang sesuai dengan jenis kelaminnya itu. Konsep gender dalam setiap budaya akan berbedabeda. Hal itu didukung oleh pendapat Oakley (1972) yang menyatakan bahwa gender tidak kaku, tetapi memiliki kecenderungan untuk mencair dan mengikuti aturan budaya yang ada dan golongan sosial laki-laki dan perempuan yang ada. Namun, pada dunia patriarkal yang cenderung dominan, perempuan dipandang sebagai obyek. Beauvoir (dalam Wibowo, 2008) menganggap bahwa perempuan, berdasarkan kelemahan biologis alami, akan selalu dijadikan sebagai bagian dari dunia laki-laki dan menjadi bukti atas kuasa laki-laki pada mereka.
Dalam konflik berbasis gender, kerapkali terjadi peng-Liyan-an satu pihak dari pihak kebanyakan. Salim mengartikan secara sederhana Liyan sebagai asing atau yang lain. Sang Liyan muncul sebagai jalan untuk membakukan sebuah citra diri, identitas sosial, dan sikap subjek. Salim (2008) menambahkan bahwa Liyan bertentangan dengan subjek. Liyan dianggap sebagai objek yang berada di luar subjek, sebagai bahan perbandingan untuk subjek sendiri. Salim mencontohkan dalam gender, perempuan kerapkali di-Liyan-kan oleh kaum laki-laki, semata karena kelemahan atau ciri biologis yang dimilikinya. Cavallaro (2004) memberikan sebuah perumpaan antara Tuan dan Budak. Tidak akan ada Tuan jika tidak ada Budak. Tidak aka nada penjajahan jika tidak ada yang bertindak sebagai penjajah maupun terjajah (Cavallaro, 2004, hlm. 119). Cavallaro (2004) lalu menjabarkan bahwa konsep ideologi Barat membakukan diri sebagai pihak yang dominan dan, di luar itu, Sang Liyan bertindak sebagai subordinat. Poststrukturalisme dianggap Cavallaro sebagai pendukung utama penempatan kelompok-kelompok marginal sebagai Sang Liyan. Ia mencontohkan posisi perempuan, gay, orang cacat, serta orang kulit berwarna sebagi Sang Liyan yang dianggap sangat menyimpang dari norma-norma patriarkal, heteroseksual, dan masyarakat kulit putih. Cavallaro juga menyampaikan bahwa budaya dominan belum dapat menerima alteritas (alternity), misalnya, perempuan dalam pandangan tradisional dianggap sebagai segala sesuatu tempat laki-laki dianggap tidak sama, sementara, laki-laki dianggap sebagai segala sesuatu yang tidak mampu dilakukan oleh perempuan (Cavallaro, 2004, hlm. 223). Cavallaro (2004) menegaskan bahwa ketika kita sedang mendiskriminasi atau memperlakukan seseorang dengan kejam orang lain, pada saat yang sama sebenarnya kita sedang mengabaikan segi-segi diri kita sendiri yang kita anggap bertentangan dengan pencarian kita atas kemewahan dan 
kestabilan. Jauh di bawah sadar, kita tidak memiliki kemampuan untuk mengompromikan orang lain dengan kita. Sang Liyan dianggap sebagai sebuah ancaman karena tidak dapat memenuhi kriteria yang dibakukan oleh budaya dominan. Cavallaro (2004) menyebut pandangan Kristeva tentang gambaran ekstrem dampak diskrimansi tersebut, antara lain, fasisme, rasisme, genosida, serta kecintaan mutlak/fanatisme terhadap teritori-bahasa-identitas nasional.

\section{METODE PENELITIAN}

Artikel ini dilandaskan pada aspek metode penelitian kualitatif dengan analisis deskriptif komparatif. Analisis terhadap keempat cerpen karya Ajidarma dilakukan berdasarkan gambaran keliyanan dan konflik gender yang muncul dalam karya tersebut. Hal-hal yang menjadi fokus penelitian lalu dianalisis berdasarkan pada konsep gender dan keliyanan yang telah dibahas dalam subbab sebelumnya. Tahapan penelitian yang penulis lakukan, antara lain, (1) pengamatan dan pembacaan mendalam terhadap data yang akan diteliti, yaitu keempat cerpen karya Ajidarma; (2) penentuan poin-poin yang akan dibahas dalam karya tersebut, yaitu poin yang menunjukkan dua fokus penelitian tersebut, gender dan keliyanan; (3) penentuan landasan teori berikut pencarian referensi yang relevan dengan topik yang akan diteliti; (4) pengolahan data; dan (5) penyusunan hasil penelitian berupa penulisan artikel ilmiah. Berdasarkan pembacaan sekilas pada beberapa karya ilmiah yang meneliti karya Ajidarma, kebanyakan mengungkapkan aspek intrinsik karya pengarang yang berkaitan dengan aspek kekuasaan, terutama pada masa rezim Orba berkuasa. Artikel ini hanyalah mengisi setitik rumpang lahan penelitian karya Ajidarma, terutama dikaitkan dengan gender dan keliyanan.

\section{PEMBAHASAN}

Pembahasan tentang gender dan keliyanan dilakukan pada keempat cerpen karya Ajidarma, yaitu "Pelajaran Mengarang", "Sepotong Senja untuk Pacarku", "Telinga", dan "Maria". Pembahasan terarah pada dua fokus berikut, yaitu gender dan keliyanan.

\section{Kritik Ajidarma atas Gender dalam Empat Cerpen}

Dalam "Pelajaran Mengarang" digambarkan tokoh perempuan yang cenderung berkutat dalam tekanan patriarki dan matriarkis sendiri. Kedudukan perempuan dalam cerpen tersebut menjadi budak berantai. Marty dipandang sebagai komoditas pemuas seks oleh kaum laki-laki yang menjadi pelanggannya. Dari sisi Marty sendiri, ia tidak menolak ketika menyanggupi kontrak tidak kasat mata dengan beberapa pelanggan eksekutif. Materi menjadi tujuan utama Marty, meskipun kepuasan batinnya tidak pernah terpenuhi. Para pelanggan tersebut tidak pernah meninggikan kedudukan Marty dalam pandangan mereka.

Sandra menjadi inferior di mata Marty yang juga sudah lama terjerat dalam inferioritas Mami. Marty berjuang keras untuk menunjukkan eksistensinya dengan memilih calon pelanggannya. Marty terkadang menjadi sumber sinisme rekanrekan sesama PSK di bawah asuhan mamih. Ia kurang disukai di kalangan para penghibur di klab malam asuhan Mami itu. Namun, Marty menunjukkan hegemoninya terhadap Sandra yang kerap kali dianggap sebagai penghalang sepak-terjangnya di dunia malam. Hal itu ia tumpahkan pada kekerasan verbal atau fisik yang diderakan pada Sandra.

Dalam "Sepotong Senja untuk Pacarku" Alina sebagai perempuan digambarkan sebagai perempuan yang pasif. Ia hanya bisa menerima keadaan yang tidak menyenangkan ketika sebuah keinginannya terpenuhi. Ia digambarkan 
sebagai inferior sementara tokoh aku sebagai superior. Tokoh aku berjuang di ranah publik dengan membawa harapan berupa "senja" kepada tokoh Alina. Alina berkedudukan sebagai perempuan pasif karena ia diposisikan sebagai penunggu harapan. Ia tidak tahu jika tokoh aku hampir menemui ajalnya karena menjadi buronan kaum petinggi yang tidak rela "asetnya" di curi oleh laki-laki itu yang dianggap sebagai minoritas.

Dalam cerpen "Telinga", dihadirkan tokoh Dewi sebagai kekasih salah seorang aparat yang pada akhirnya selalu kehausan untuk memenggal telinga dan kemudian kepala para warga yang dianggap sebagai pemberontak. Dewi digambarkan sebagai perempuan yang dibutakan dengan pemberian kekasihnya. Ia juga digambarkan sebagai perempuan yang mudah menerima gratifikasi sehingga sebuah kejahatan di matanya menjadi arena kebangkitan kepahlawanan kekasihnya. Dewi menganggap kekasihnya sebagai pahlawan, meskipun pada kenyataannya ia menjadi pembunuh bayaran yang ditugaskan negara untuk menumpas pemberontakan di sebuah daerah konflik. Perempuan digambarkan sebagai inferioritas dengan segala kelemahannya. Tidak tertutup kemungkinan Dewi dihadirkan sebagai simbol atas kelemahan negeri ini dalam menghadapi konfliknya sendiri. Tidak mampu mandiri dalam menangani berbagai permasalahan negeri, mudah bergantung pada bantuan orang lain, meskipun bantuan tersebut bukan semata bantuan sosial. Di balik itu, ada sederet syarat berat yang harus ditanggung negeri ini untuk mendapatkan bantuan itu.

Dalam cerpen "Maria", Maria dan Evangelista digambarkan sebagai sosok inferior yang sempit pola pikirnya. Mereka terkurung sekian lama di balik tembok rumah setelah kehilangan suami dan anakanak mereka. Ketergantungan kepada sosok maskulin tampak jelas pada diri kedua perempuan itu yang tenggelam dalam duka yang panjang atas kehilangan suami dan anak-anak mereka. Sempitnya pola pikir kedua perempuan itu tampak jelas terlihat ketika mereka tidak dapat menerima Antonio dalam kondisi yang sangat di luar perkiraan mereka. Kedua perempuan itu tidak dapat menerima perubahan dalam satu waktu. Pola-pola baku tentang siapa Antonio dalam pikiran mereka sulit dilepaskan begitu saja. Maria dan Evangelista merupakan simbol kelemahan negeri ini yang sulit beranjak dari keterpurukan, ketergantungan kepada pihak luar yang dianggap lebih maskulin, meskipun dengan risiko yang sangat tinggi. Antonio dianggap sebagai sosok maskulin yang seolah kalah di hadapan sosok feminin yang semula diharapkannya untuk menjadi tempat bernaung dan berbagi. Antonio tidak dianggap sebagai sosok yang kelak mampu menjadi nakhoda di rumah itu. Jika diibaratkan pada kondisi negeri ini, Antonio merupakan orang yang berbakat (seniman musik) yang dapat mengangkat derajat orang tuanya. Banyak orang berbakat yang sesungguhnya dapat mengharumkan negeri ini lalu ditolak di rumahnya sendiri dan pada akhirnya lebih memilih pergi ke negeri asing dan berkiprah di tempat itu. Kasus dr. Warsito dengan teknik pengobatan kanker elektroniknya merupakan salah satu lemahnya bangsa ini dalam menghargai potensi anak negeri. Tidak mengherankan jika negeri ini ibarat Maria dan Evangelista yang tenggelam dalam kesempitan dan kegelapan.

Dari keempat cerpen tadi, sosok perempuan digambarkan sebagai pihak pasif dengan pola pikir tradisional. Pengotak-kotakan wilayah domestik-publik sangat dilandasi oleh pandangan bias gender. Jika ada perempuan yang berusaha untuk keluar dari zona nyaman, ia akan menemui kesulitan atau kesengsaraan seperti yang digambarkan oleh Marty. Tekanan patriarkis pada kehidupan perempuan dalam keempat cerpen juga menyudutkan mereka pada posisi inferior. Ketidakdayaan untuk menyatakan gugatan, atau sekadar membuka pikiran, dianggap 
sebagai hal yang kurang lazim. Konflik femininitas dalam "Pelajaran Mengarang" menimbulkan budaya persaingan pada sesama PSK dalam asuhan Mami. Marty menumpas persaingan tersebut dengan merebut beberapa pelanggan eksekutif. Dewi dalam "Telinga" dibutakan matanya oleh kekasihnya. Kejahatan laki-laki di ranah publik dianggap sebagai hal yang biasa. Alina juga tidak tahu menahu beratnya membawa aset negara meskipun hanya satu inci ke dalam ranah domestik. Ia membutakan matanya karena cinta. Kata cinta dianggap sebagai sarana untuk melanggengkan peranan patriarkis dalam kehidupan. Dalam "Maria" perang merupakan doktrin maskulinitas besar yang melanda terutama pada kaum perempuan dan anak-anak. Perang menekankan rasa takut yang berlebihan pada mereka. Maria dan Evangelista mengalami hal itu. Mereka tidak dapat berpikir jernih ketika menghadapi perubahan yang drastic pascaperang. Rasa takut yang luar biasa membuat mereka untuk menginci diri dalam zona nyaman, meskipun dalam satu sisi, mereka masih memerlukan kehadiran sosok maskulin, Antonio.

\section{Kritik Ajidarma atas Keliyanan dalam Empat Cerpen}

Dalam "Pelajaran Mengarang", keliyanan terjadi secara turun-temurun. Sandra mengalami hal itu sebagai anak dari seorang wanita penghibur. Ibunya, Marti, bekerja sebagai wanita penghibur di sebuah bar merangkap sebagai PSK secara mandiri. Kedudukan sebagai perempuan penghibur menyebabkan Marty tersudutkan oleh lingkungannya sendiri, terutama, para pelanggan, Mamih, dan nasibnya sendiri. Hal itu tidak jarang menimbulkan frustrasi yang liar dalam hidup Marty. Tidak jarang, ia me-Liyan-kan anaknya sendiri dengan mencap Sandra sebagai "anak setan" atau "anak jadah". Kata setan dan jadah sendiri sudah lama menjadi cap bagi Marty dan juga perempuan lain yang seprofesi dengannya.
Marty yang kesepian karena kehilangan cinta sejati dan impian untuk membangun keluarga ideal, lalu meluapkan kepedihannya pada jalur yang kelam, sebagai perempuan penghibur. Marty hamil, tetapi entah siapa laki-laki yang harus ia tuntut untuk bertanggung jawab. Di satu sisi, naluri keibuannya muncul dan membiarkan janin tumbuh dalam tubuhnya. Ia menjadi orang tua tunggal bagi Sandra. Marty yang kehilangan konsep keluarga ideal, lalu menumpahkan frustasinya kepada Sandra ketika ia merasa kesal, belum mendapatkan pelanggan atau menaruh kekecewaan pada pelanggannya itu. Marty seolah menjadi dua sisi yang berlawanan. Pada satu sisi, ia mampu bertindak sebagai ibu yang baik, tetapi kebanyakan waktunya tersita sebagai ibu yang tidak ideal.

Namun, wanita itu tak selalu berperilaku begitu. Sandra lebih sering melihatnya dalam tingkah laku yang lain (Ajidarma, 1996, hlm. 4).

Sandra kerapkali mendapatkan makian dan diperlakukan dengan tidak manusiawi.Lebih parah lagi. Dalam kondisi tidak sadarkan diri, karena pengaruh minuman keras, Marty melayani pelanggannya di depan Sandra yang dikiranya tertidur.

Dampak perlakuan Marty, tanpa disadari, mengaburkan Sandra dari konsep keidealan sebuah keluarga.Sandra merasa ter-Liyan-kan dalam sebuah ruang kelas ketika pelajaran mengarang tiba. Sang guru, Ibu Tati, seolah bertindak sebagai ratu di dalam kelas yang berhak untuk menentukan tema dalam pelajaran mengarang. Tema yang dipilih saat itu adalah keluarga bahagia, satu hal yang tidak akan pernah Sandra temui dalam hidupnya. Tidak satu kata pun dalam otak Sandra yang mampu tertuang pada lembar kertas kosong itu. Sandra harus memutar otak untuk mengemas sebuah bingkisan kata yang layak dituangkan ke dalam kertas tentang sosok keluarganya. Yang ia miliki hanya 
seorang ibu. Ibu yang tubuhnya indah dan wajahnya cantik, tetapi perokok dan pemabuk dengan perangai yang dianggap tidak layak ditunjukkan oleh seorang perempuan berkriteria cantik. Sandra harus menguraikan simbol-simbol yang mampu membentuk rangkaian kata tentang ibunya. Dia ingat bagaimana ia melihat sang ibu bekerja di tempat hiburan, bagaimana sang ibu "bekerja" di rumah sementara ia diselundupkan di bawah dipan, bagaimana sang ibu bereaksi terhadap pelanggannya, sikap sang ibu dalam keseharian di rumah dan ketika sedang di luar rumah, kode-kode yang selalu bermunculan pada layar pager yang selalu ia baca, dan sebagainya. Buah kerja keras Sandra lalu tertuang dalam sebuah kalimat singkat yang cukup menohok sang guru, "Ibuku seorang pelacur".

Perempuan dalam hampir budaya kebanyakan cukup termarginalkan kedudukannya dalam kacamata sosial. Perempuan yang dianggap sebagai warga lapis kedua cenderung dipantaskan hanya pada ranah domestik, hingga hadir pembatasan ruang aktivitas khusus perempuan (dalam budaya Jawa, misalnya): sumur, dapur, kasur. Perempuan dianggap sebagai konco wingking yang posisinya selalu berada di balik punggung laki-laki dengan segala kelemahannya.Terlebih bagi perempuan penghibur, seperti Marty. Kedudukan mereka ibarat dua sisi mata uang. Pada satu sisi, mereka dibutuhkan untuk pemuasan hasrat kaum patriarki. Namun, pada sisi lain, mereka disudutkan sebagai pelaku profesi yang paling hina. Dampaknya, stigma yang sudah dibakukan selama bertahun-tahun, senantiasa hadir dalam setiap generasi. Masyarakat, perempuan dan laki-laki, tidak menerima kehadiran perempuan seperti Marty. Namun, sebagian laki-laki memperlakukan mereka dengan tidak adil, mencela tetapi sekaligus menjadikan mereka sebagai lahan alternatif pencari kepuasan.

Sandra dan Marty ibarat gambaran manusia yang termarjinalkan dalam kehidupan urban. Keduanya hidup dalam bilik-bilik yang terbatas. Marty terbatas pada kekuasaan seorang Mami dengan sederet keharusan yang patut dipatuhi jika ingin tetap berkibar di tempat hiburan itu. Selain itu, hidup Marty juga sangat bergantung pada belas kasihan pelanggannya yang wujudnya ibarat fatamorgana. Ada tetapi sulit dijamah dalam kehidupan nyata. Para pelanggan yang matanya hanya tertuju pada kecantikan wajah dan keindahan tubuh Marty. Kebahagiaan Marty merupakan kebahagiaan semu. Marty boleh jadi mendapatkan kontrak dari pelanggannya selama beberapa hari. Namun, apa yang ia peroleh bukan kebahagiaan hakiki. Hasil yang ia dapatkan dibagikannya kepada Sandra, tetapi anak itu menganggapnya pula sebagai kebahagiaan semu karena kebanyakan ia menghadapi sosok ibu yang lain. Kehidupan Marty adalah kehidupan materi.Batin manusia yang tidak pernah terisi lalu menyebabkan frustrasi yang parah. Manusia di piah-pilah dengan ruangruang yang terbatas, dengan penguasa yang berkuasa di ruang itu, dengan kuasa di atas penguasa ruang sempit itu membentuk hirarki. Dunia materi pada rezim yang lalu yang dipenuhi dengan hukum rimba, siapa yang ingin bertahan (disimbolkan dengan keberhasilan Marty memperoleh pelanggan kaya), tetapi dihadang dengan konsekuensi yang berat.

Sandra menghadapi kehidupan yang sulit. Hidupnya dibatasi ruang-ruang frustrasi ibunya, terbatasnya koneksi dengan teman sebayanya, dan keinginannya yang terpasung. Sandra dibutakan dengan doktrin Marty agar ia tidak banyak bicara dan mempertanyakan keberadaan ayahnya. Pengekangan Sandra merupakan simbol atas pengekangan serupa pada kelompok marginal dalam suatu pemerintahan otoriter. Penderitaan yang berkepanjangan mendorong Sandra untuk membebaskan diri. Namun, Sandra tidak pernah dilatih untuk mengembangkan diri dan mengatasi masalah. Ia hanya bisa memendam 
keinginan itu dalam-dalam. Hal itu diungkapkan dalam kutipan berikut.

Sandra masih memandang ke luar jendela. Ada langit yang biru di luar sana. Seekor burung terbang dengan kepakan sayap yang anggun (Ajidarma, 1996, hlm. 4).

Sandra melayangkan pandangan ke luar jendela tempat hiburan. Hal itu menyiratkan bahwa apa yang ada di luar sangatlah luas. Hal itu menggoda Sandra untuk melambungkan keinginaanya berada di luar ruang yang mengekangnya. Ketidakmengertian Sandra terhadap penempatan para perempuan di sebuah tempat yang tertutup kaca digambarkan bahwa manusia pada rezim masa lalu tidak dibiarkan untuk berpikir panjang, berwawasan luas, dan memiliki pemahaman yang mendalam. Jika Sandra bersuara, akan ada sanksi berat yang diterimanya dari Marty. Satu hal yang patut dilakukan oleh Sandra di mata Marty sebagai penguasa adalah tutup mulut dan menurut. Burung terbang merupakan simbol kebebasan hidup di lahan yang seolah tidak terbatas (langit). Burung juga menjadi simbol perdamaian. Sandra merindukan kehidupan yang bebas dan damai. Ia ingin lepas dari sekat-sekat ruang hidupnya saat ini. Sebagai catatan, masih ada penguasa lain yang turut menyudutkan posisi Sandra, yaitu Ibu Guru Tati yang memaksanya memaknai sebuah dunia yang sama sekali asing baginya, keluarga.

Sementara itu, "Sepotong Senja untuk Pacarku" bercerita tentang perjuangan seorang aku untuk memberikan benda yang sangat diinginkan kepada pasangannya itu. Namun, apa yang diinginkan sang kekasih bukanlah barang yang bebas pakai, melainkan bagian dari benda alam yang sudah dikuasai oleh negara. Tidak heran, kekasih pun harus mengalami peristiwa yang cukup miris, pengejaran oleh aparat hingga tempat tersulit sekalipun. Sekeping senja itu pada akhirnya sampai sampai juga di tangan sang kekasih yang bernama Alina.
Tokoh aku diibaratkan seorang Robin Hood yang berbuat baik dengan cara hina, mencuri. Apa yang ia curi bukanlah benda yang mahal, hanya sepotong senja. Kata senja dalam $K B B I$ seri luring (luar jaringan) bermakna waktu hari setengah gelap sesudah matahari terbenam. Senja dan fajar pada saat kemunculannya selalu memberikan pemandangan yang sangat indah. Nuansa keemasan hadir di tengah perubahan awan yang gelap. Sepotong senja dalam cerpen tersebut bukan bermakna halhal yang berbau kelam, melainkan harapan, kebahagiaan, atau kesempatan emas yang dapat dinikmati oleh Alina sebagai seorang perempuan dan sebagai seorang rakyat di tangah penguasa. Namun, senja merupakan bagian dari alam. Alam menjadi milik kekuasaan dan sang penguasa. Penggunaan alam harus seizin sang penguasa. Pemotongan senja oleh tokoh aku dianggap sebagai tindakan kejahatan subversif, meskipun tokoh tersebut sudah menggantinya dengan benda yang sangat mirip. Pascareformasi, kerapkali muncul pencubitan kekayaan alam, meskipun dalam jumlah yang remeh temeh, yang dianggap sebagai tindakan kriminalitas kelas tinggi. Ingatkah kita pada kasus seorang nenek buruh kebun singkong yang dianggap mencuri hasil kebun, padahal ia hanya mengambil beberapa batang singkong yang tidak seberapa besarnya? Kasus pengambilan satu-dua buah cokelat yang dilakukan buruh renta? Kasus penganiayaan atau pembunuhan warga yang berusaha mempertahankan tanah-tanah miliknya? Kasus "pembersihan" warga yang vokal terhadap hak asasi minoritas? Harapan dan kebahagiaan seakan hanya mutlak menjadi milik pendudukan kelas tinggi dan eksklusif. Kaum minoritas dan marginal seolah tidak dibiarkan untuk menikmati kebahagiaan. Alina adalah seorang perempuan. Ia bukan siapa-siapa. Ia hanya menginginkan setitik kebahagiaan melalui kebaikan kekasihnya. Namun, keinginan Alina dianggap sebagai sesuatu yang berlebihan dan merusak kebahagiaan para 
pemilik kekuasaan. Kekasihnya menjadi buronan bahkan ketika ia sudah mengganti benda yang hilang itu. Rakyat kecil itu terpaksa menyelinap dan bersembunyi ke sebuah tempat yang terpencil. Penguasa tidak membiarkan hartanya hilang sedikit pun dengan mengerahkan aparat yang tunduk kepadanya. Ke mana pun tokoh aku pergi, ia selalu diburu. Nasib Alina menggantung hingga akhir cerita. Hal itu menyiratkan masih banyaknya urusan publik yang menggantung tanpa penyelesaian. Bantuan kepada tokoh aku didapatkan oleh seseorang yang tinggal di dalam sebuah lorong. Lorong merupakan sebuah tempat yang gelap yang digunakan sebagai tempat untuk berlalu dan menuju ke tempat lain, atau saluran untuk mengalirkan sesuatu, misalnya saluran air kotor. Lorong bukanlah tempat yang menyenangkan. Tempat itu dijadikan sebagai sarana perlindungan bagi rakyat kecil. Artinya, minoritas selamanya akan tersudut pada tempat-tempat yang sulit. Hal itu digambarkan dengan kalimat seorang gelandangan yang membantu menyelamatkan tokoh aku.

"Masuklah, kamu tidak punya pilihan lain." (Ajidarma, 1996, hlm. 14).

Lorong dalam cerpen tersebut menjadi istana yang layak bagi para marginal. Di tempat itu terdapat harapan dan kebahagiaan hanya untuk mereka. Hal itu digambarkan dengan munculnya pantai yang tidak kalah indah dan hampir menyerupai tempat tokoh aku ketika menemukan senja di dunia atas. Hal itu menyiratkan adanya hirarki yang jelas, feodalisme. Status sosial menentukan fasilitas yang layak dinikmati.

Tangga itu menuju ke sebuah mulut gua, dan tahukan kamu ketika aku keluar dari gua itu aku ada di mana? Di tempat yang persis sama dengan tempat di mana aku mengambil senja itu untukmu Alina. Sebuah pantai dengan senja yang bagus: ombak, angin, dan kepak burung-tak lupa cahaya keemasan dan bias ungu pada mega-mega yang berarak bagaikan aliran mimpi. Cuma saja tidak ada lubang sebesar kartu pos. jadi, meskipun persis sama, bukan tempat yang sama. (Ajidarma, 1996, hlm. 15).

Cerpen "Telinga" bercerita tentang genosida. Dalam gaya cerita dalam cerita, telinga menjadi komoditas yang diberikan oleh seorang aparat yang sedang bertugas di sebuah ranah konflik. Telinga tersebut dijadikan sebagai hadiah bagi sang kekasih. Benda itu bukan merupakan mainan, melainkan telinga sungguhan. Telinga para korban penembakan aparat di daerah konflik. Telinga merupakan alat untuk mendengar. Sebuah daerah konflik yang terletak sangat jauh dari pusat pemerintahan seolah tertinggal dalam segala hal. Daerah tersebut cenderung menjadi "bulanbulanan" kaum penguasa. Eksploitasi budaya dan kekayaan alam tidak terkendali sementara penduduknya dibiarkan tertinggal. Ketidakadilan dalam pembangunan menyebabkan terjadinya pemberontakan penduduk setempat. Dengan mudah, penguasa mengerahkan aparat untuk meredakan hal itu. Aparat seolah diberi keleluasaan untuk melakukan apa saja asalkan mampu meredam kericuhan, di antaranya dengan memberikan ancaman yang cukup istimewa. Siapa saja yang dianggap membahayakan keamanan di daerah itu, harus menjalani hukuman potong telinga. Hal itu dilakukan untuk memberikan peringatan kepada warga lainnya agar tidak berbuat hal serupa.

Kami memang biasa memotong telinga orang - orang-orang yang dicurigai, sebagai peringatan atas risiko yang mereka hadapi jika menyulut pemberontakan (Ajidarma, 1996, hlm. 87).

Aspek kemanusiaan tidak berlaku di tempat itu. Pembungkaman terjadi secara brutal dengan kemasan yang cukup indah. Doktrinasi terjadi bukan hanya kepada warga yang dianggap sebagai pemberontak, melainkan pada aparat yang menjalankan 
tugas pemberantasan konflik. Darah dan kekerasan menjadi sekolah yang membentuk efek sadistis pada diri aparat. Ia dibuat bebal dan matanya dibutakan tugasnya sendiri. Semua warga dianggap sebagai musuh. Tugas untuk mengamankan lambat laun menjadi sarana untuk melakukan pembantaian. Hati nuraninya sudah terkikis. Frustrasi bukan muncul di tengah warga, melainkan pada aparat keamanan sendiri.

"Maria" bercerita tentang seorang ibu yang tidak hentinya menantikan kedatangan anak kesayangannya dari peperangan. Cerpen tersebut bercerita tentang perempuan-perempuan yang kehilangan para laki-laki. Maria dan Evangelista samasama kehilangan suami dan anak-anak lakilakinya. Para laki-laki itu dikabarkan hilang di kancah perang. Maria masih mengharapkan kehadiran dan kepulangan kembali Antonio. Tidak seperti kakak dan ayahnya, Antonio bukanlah laki-laki yang memiliki kepiawaian perang yang hebat. Ia merupakan seniman sejati dan anak kesayangan ibu. Ketika ia menjadi satusatunya laki-laki, ia diharapkan akan menjadi nakhoda bagi ibu dan tantenya. Namun, ia tidak dapat menghindari ketentuan perang bagi kaum laki-laki. Ranah publik tampak menelan secara mutlak bakat dan keinginan Antonio pribadi. Ia mengalami penculikan dan penyiksaan yang cukup parah sehingga rusak fisik dan psikisnya.

Sayangnya, Maria dan Evangelista tidak dapat menerima kehadiran Antonio sebagai anggota laki-laki di rumah itu dengan tubuh yang hampir tidak dapat dikenali. Antonio dimarjinalkan orang rumahnya sendiri. Jerih payahnya untuk kembali ke rumah menjadi sia-sia. Ibu yang diharapkannya menjadi pelabuhan hatinya, lalu menolak dirinya mentah-mentah. Penolakan tersebut berakhir menyedihkan. Antonio kembali ke jalanan dan harus menjalani hidup yang tidak menentu. Maria dan Evangelista mengakhiri penantian panjangnya untuk Antonio. Keduanya menutup pintu rumahnya sendiri dan terpuruk dalam trauma berkepanjangan atas peristiwa itu. Mereka menghindari kedatangan orang asing ke rumahnya.

\section{PENUTUP}

Kritik sosial Ajidarma hadir sebagai wujud kepekaan tinggi dalam membaca situasi dan kondisi lingkungan dan negeri ini. Pengetahuan yang luas dan kepiawaian dalam merangkai kata, membuat Ajidarma mampu melahirkan karya sarat pesan dengan kemasan yang sangat indah.kritik sosial yang muncul dalam keempat cerpen berikut: "Pelajaran Mengarang", "Sepotong Senja untuk Pacarku", "Telinga", dan "Maria" terarah pada dua fokus berikut, yaitu gender dan keliyanan.

Konflik gender terjadi karena karena kehilangan. Konflik tersebut seolah tidak pernah terselesaikan karena tokoh perempuan tidak pernah diberikan lahan untuk mengembangkan pola pikirnya dan berlatih menuntaskan penyelesaian konfliknya. Konflik gender dalam penelitian mengarah pada inferioritas. Hal itu menyebabkan tokoh perempuan mengalami keterbatasan dalam pola pikir dan penyelesaian konflik.

Keliyanan terjadi karena dikotomi perempuan dan laki-laki. Tokoh perempuan di-liyan-kan atas eksistensi laki-laki. Keliyanan perempuan menyebabkan tersudutnya mereka pada marginalitas. Namun, kondisi sebaliknya terjadi pada pada cerpen "Maria", tokoh Antonio diliyan-kan oleh keluarganya sendiri yang notabene terdiri dari para perempuan.

\section{DAFTAR PUSTAKA}

\section{Ajidarma, S. G. (1993a). Maria. Kumpulan Cerpen Kompas 1993 Pelajaran Mengarang. Jakarta: Kompas.}

Ajidarma, S. G. (1993b). Pelajaran Mengarang. Kumpulan Cerpen Kompas 1993 Pelajaran Mengarang. Jakarta: Kompas. 
Ajidarma, S. G. (1993c). Sepotong Senja untuk Pacarku. Kumpulan Cerpen Kompas 1993 Pelajaran Mengarang. Jakarta: Kompas.

Ajidarma, S. G. (1993d). Telinga. Kumpulan Cerpen Kompas 1993 Pelajaran Mengarang. Jakarta: Kompas.

Ajidarma, S. G. (1996). Jazz, Parfum, dan Insiden. Yogyakarta: Bentang.

Biantoro, B. A. (2012). Kritik Sosial dalam Novel Kalatidha Karya Seno Gumira Ajidarma: Tinjauan Sosiologi Sastra. (Skripsi). Surakarta: Universitas Muhammadiyah Surakarta.

Bressler, C. (2002). Literary Criticism. London: Prentice- Hall International.

Cavallaro, D. (2004). Critical and Cultural Theory. Edisi terjemahan oleh Laily

Rahmawati. Yogyakarta: Niagara.

Didipu, H. (2013). Fungsi Sastra. Diakses 12 Juni 2017, melalui http://dosen.ung.ac.id/herdi/home/201 3/1/9/fungsi_sastra.html

Holmes, M. (2007). What is Gender: Sosiological Approaches. London: Sage Publications.

Indra, A. B. (2015). Wacana Kekuasaan dalam Karya Seno Gumira Ajidarma, Penembak Misterius dan Saksi Mata. dalam D. Suryaman, Maman (Ed.), Bahasa, Sastra, dan Kekuasaan. Yogyakarta: Interlude.

Nurhadi. (2004). Analisis Hegemoni pada Iblis Tidak Pernah Mati Karya Seno Gumira Ajidarma. Jurnal Litera, 25(Juli).

Oakley, A. (1972). Sex, Gender, and Society. London: Temple Smith.

Ratna, N. K. (2008). Teori, Metode, dan Teknik Penelitian Sastra. Yogyakarta: Pustaka Pelajar.

Salim, D. R. (2008). Deskripsi Toleransi dan Intoleransi di Kalangan Anak
Muda di Jerman dalam Novel "Und Wenn Shon!" dan "Steingesicht"Karya Karen Susan Fessel. (Skripsi). Depok: FIB, Universitas Indonesia.

Sarumpaet, R. K. (2010). Pedoman Penelitian Sastra Anak. Jakarta: Pusat Bahasa Indonesia.

Wibowo, A. (2008). Simon De Beauvoir: Feminisme Eksistensialis. Diakses 16 Oktober 2017, melalui http://staff.blog.ui.ac.id/arif51/2008/07 /28/simon-de-beauboir-feminismeeksistensialis/ 